\title{
Training Google Form as an Online Learning Evaluation Tool for Teachers at SDN Nusa Indah Subang Using the Method KuIWApp
}

\author{
Efrina Aryani, and Syifaul Fuadaa) \\ Universitas Pendidikan Indonesia, Bandung, Indonesia \\ a)Corresponding author: Syifaulfuada@upi.edu
}

\begin{abstract}
A workshop on making Google Form-based learning evaluation questions for teachers at the Elementary School of Nusa Indah, Dangdeur Village, Subang District, West Java Province, was held successfully on December 5,2020 . This workshop aims to assist elementary school teachers in providing interesting online learning evaluations (not monotonous learning); this happens because so far, the assignment for evaluation purposes has only been carried out through the chat method (WhatsApp group), where the problem found is the teacher has difficulty recapitulating the student's assignments result. Later, the students get bored quickly because there is no variation in online evaluations, and parents have difficulty understanding the questions photographed by the teacher. Five teachers attended the training, carried out textually on the WhatsApp group. The implementation of this workshop runs smoothly, as expected. Therefore, the goals can be achieved in terms of teachers, students, and parents' perspectives. The teacher can create simple questions on Google form. To implement this workshop, long-distance learning barriers in the Elementary School of Nusa Indah, especially related to assignments/online evaluation, can be overcome.
\end{abstract}

Keywords: Learning evaluation tool, Google form, online learning, Thematic student community services, WhatsApp group

\section{INTRODUCTION}

The existence of the Covid-19 pandemic has changed human life in various sectors, including the economy and human life in social life (Ritonga et al., 2020). As a result, teaching and learning activities in Indonesia, including the Subang Regency, West Java Province, must change from face-to-face interaction methods to distance learning, or commonly called faceto-face (learning online). Each student and teacher carry out teaching and learning activities in their respective homes. Distance learning has been running since March 2020 concerning the Circular Letter of the Ministry of Education and Culture No. 40 of 2020. For this reason, teachers who are the key to running education at the primary to secondary level are required to be innovative in developing the learning process, looking for appropriate learning methods and models by existing conditions to collaborate with digital media (Fahrudin, 2020).

However, in reality, many problems occur in implementing distance learning, so it is not optimal. Such is the case found in one of the elementary schools in the Subang area, namely SDN Nusa Indah. This school only runs online learning practices by using WhatsApp Groups simultaneously. However, the results of interviews with teachers, students, and parents yielded information that the learning process through chat on the WhatsApp group was deemed not optimal because the teacher carried out passive learning, namely giving assignments without material introduction. As a result, students' interest in learning decreases.

On the other hand, collecting student assignments in WhatsApp groups is difficult for the teacher to manage because it is in the form of photos, so the teacher needs to sort out photos of student work. Giving assignments on WhatsApp and sending student work makes it crowded, so it is less comfortable for students and can consume memory smartphones. Both teachers and students in WhatsApp groups should always delete chats discussions periodically. SDN Nusa Indah teachers have not widely explored alternative learning media in 
online classes, both from creative video-based delivery materials or online evaluation tools. Until now, they are still using the application WhatsApp only.

From these problems, it is necessary to have supporting media for the convenience of the student learning process other than the WhatsApp group at SDN Nusa Indah focused on providing online evaluation tools. Even though schools are conducting distance learning due to the current pandemic conditions, student learning evaluations must still be held so that the evaluation function itself can be measured by teachers (Z. Arifin, 2009). Distance learning, in collaboration with the latest technological media, can provide more varied learning resources (Dewi, 2020) (R. Kurniawati \& S. Fuada, 2021). Therefore, we proposed a solution proposed by implementing the google form as a tool and online evaluations. With this tool, the distance learning at SDN Nusa Indah is not monotonous in WhatsApp groups only. Later, online learning becomes more varied, not limited to giving assignments from photos of student worksheets. Practice questions that can be used in Final Exam Week using Google forms can be a support in increasing students' enthusiasm for learning. Educators have widely used Google forms in this learning evaluation because it offers several impressive features. Google forms are easy to access by just having a GMAIL account, free with large storage capacity (connected with Google Drive up to $20 \mathrm{~GB}$ ), and easy to create/operate, and easy to deploy/share to save time and effort in asking questions one by one to the person concerned. Google forms can also display interpretation data with exact percentages, such as in the form of pie charts, bar charts, Etc. It is easy for users to process the data/statistics obtained further with SPSS because Google forms are integrated with Google Spreadsheets which, when downloaded, become files MS. Excel. Google forms can minimize the use of printed paper in making questionnaires. Then, the other most important thing is that the Google form has a simple display. The layout is easy for users (Azis \& Salihah, 2020), (Arifin, 2017).

This program aims to introduce new media for SDN Nusa Indah teachers, namely Google forms and training on procedures for using and creating questions with Google forms. The training materials include creating an account, starting work on the Google form, introducing the features in the Google form, and how to process data/values when students' answers are entered. The training media Google form for SDN Nusa Indah teachers is completely online, namely using WhatsApp groups or, in familiar terms, KulWapp. This method was chosen for the following reasons:

1. It was implementing campus policies that require all real work lecture activities to be carried out online to prevent the occurrence of new clusters of Covid-19 infected (Thematic Real Work Lecture Guidelines for Prevention and Mitigation of the Impact of Covid-19 Universitas Pendidikan Indonesia Universitas Pendidikan Indonesia, nd).

2. Media WhatsApp has been known and mastered by teachers very well because learning has used this media so far, so it feels there is no problem in delivering training materials.

3. WhatsApp is easy to access and quota-friendly compared to Zoom or Google Meets.

4. Based on an agreement between teachers as training participants, the method KulwApp can be more efficient because if the teacher forgets the training material, it can be scrolled up again.

\section{METHOD}

The training is carried out in several stages, including the following:

1. The program preparation stage begins with consultation and coordination with Field Supervisors (DPL), making leaflets, then distributing pamphlets in WhatsApp groups containing staff and teachers at SDN Nusa Indah.

2. The core stage begins with giving a speech, giving video tutorials, followed by discussions, and making Google forms independently at each teacher's home. Results were reported in the WhatsApp group. The activity was carried out for one day through the WhatsApp group (Saturday, December 5, 2020) and was attended by five teachers of SDN Nusa Indah. 
3. In the evaluation stage, the executor uses the interview method in private chat on WhatsApp. The evaluation aims to find out how the response of the training participants.

\section{Preparation Phase}

\section{RESULTS AND DISCUSSION}

Before the activity was carried out, activity pamphlets were prepared under the guidance of the lecturer (Figure 1). Then, this pamphlet was distributed to a WhatsApp group containing teachers from SDN Nusa Indah (Figure 2a). To maximize the number of participants, the organizers made an invitation through a private chat on WhatsApp in addition to the large group of SDN Nusa Indah (Figure 2b). The pamphlet was created using the Canva application that contains important information such as the event's name, the time and place of the event, online training materials, and information about the organizers.

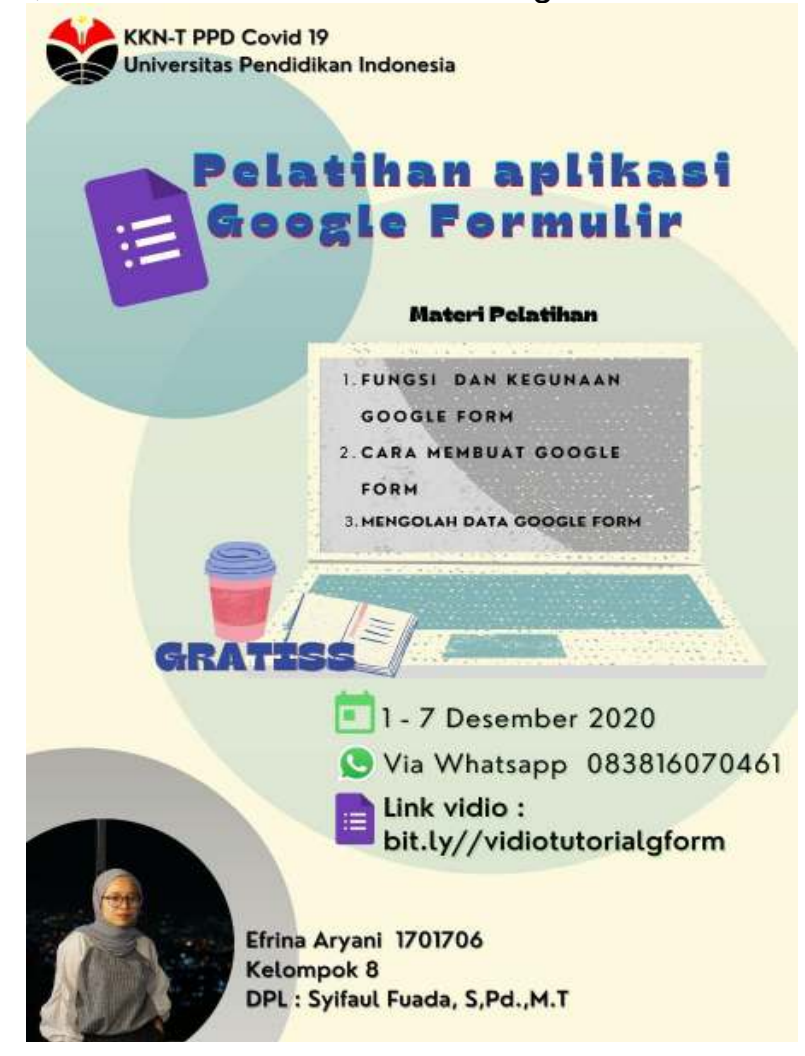

Figure 1. Training activity pamphlet Google form

In addition to distributing flyers and invitations, we include a description or overview of the Google form and its benefits. The goal is to attract the number of participants and motivate potential participants to learn new things related to making online learning evaluation questions using Google forms. The target participants are the teachers of SDN Nusa Indah, while educators are not the target of this training. This initial activity (invitation and socialization) coincided with including link material in Youtube videos. The initial video that was shared was an introduction and explanation of the basic functions of Google forms. In this workshop, the teacher already has a draft of the questions by the subjects being taught (following the existing syllabus). Therefore, during practice, all of the participants have to enter the questions already available. Of course, the training time will run effectively and efficiently (fast). For this reason, only five teachers are ready to take part in this program out of 15 total teachers at SDN Nusa Indah Subang. The five teachers are also categorized as senior teachers (elderly) who are not familiar with Google forms. 


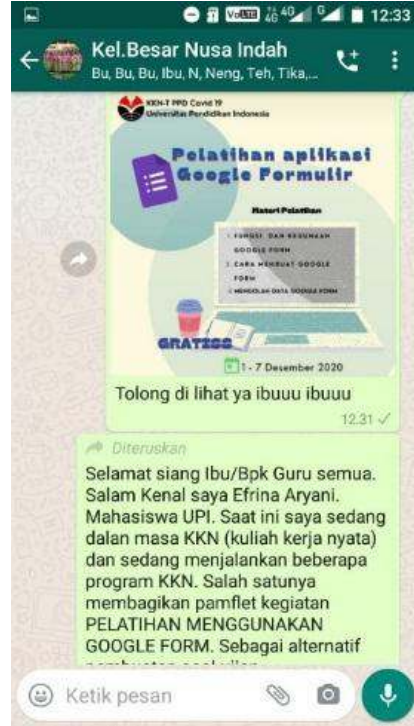

(a)

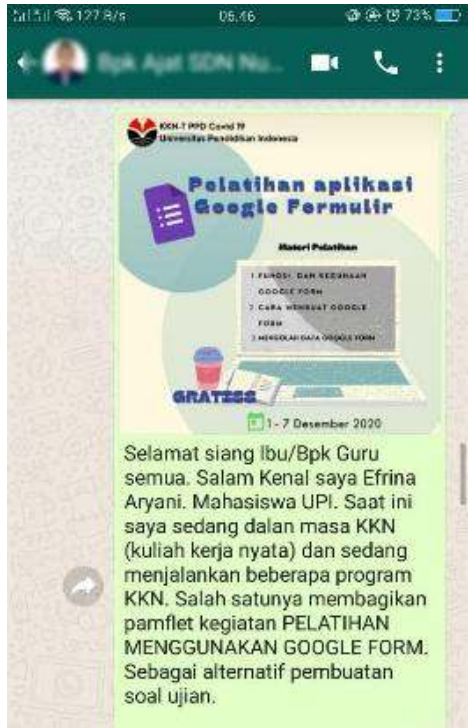

(b)

Figure 2. Distribution of flyers through (a) WhatsApp group and chat personal on WhatsApp

\section{Core Stage}

After the organizers find participants interested in joining the program, a WhatsApp group is specially created. First, the participants were given a video material containing a complete tutorial on making evaluation questions with Google forms and how to manage the results after the audience or students filled in the questions. Then, the organizer gives time for the activity participants to watch the video tutorial. After about an hour, the participants watched the video carefully, and we followed up with the participants to ask their level of understanding after watching the video. The discussion activity after watching this video is also useful if there are participants who still do not understand how to make Google forms.

Participants did not ask many questions in the discussion session because they already felt it was clear (Figure 4). Participants who do not have questions to discuss are then immediately directed to practice making evaluation questions independently. In this session, all participants create questions and generate URLs. The link was a question sent in the group WhatsApp and reviewed by the administrator (Figure 4). The results show that all participants (five teachers) succeeded in making simple questions for online exams based on Google forms. Table 1 is an indicator of the success of program implementation in terms of the initial conditions of teachers, students, and parents.

From a student's point of view, the use of Google forms can increase enthusiasm/motivation to learn (Cristian, 2017) because Google forms can provide access to multiple questions. Hence, besides being easy to evaluate student's fill out and immediately know the results. If it is felt that the value is lacking, students will continue to study to get a perfect score. Google Forms can be arranged so that every question that has been answered immediately shows a value or does not appear and is only filled out once. This setting is adjusted to field conditions; if the teacher wants students not to try and focus on the value (not the process), the teacher can set the token, time, duration, one-time filling, and no value appears. Although students may fill in multiple times, teachers can view data in Google Spreadsheets to classify students' fill-in through learning outcomes or trial and error. If students fill in answers by trial and error (memorization of correct answers), they input many data. Existing technology will function optimally according to its designation if the teacher can use it properly (NWA Majid et al., 2020: 250-258), (Majid et al., 2020: 133-145), technology accompanied by a teacher's touch will produce learning that is not monotonous whether it is 
done face-to-face or face-to-face. This training on making questions with Google forms is one of the efforts to facilitate teachers in achieving these defined parameters.

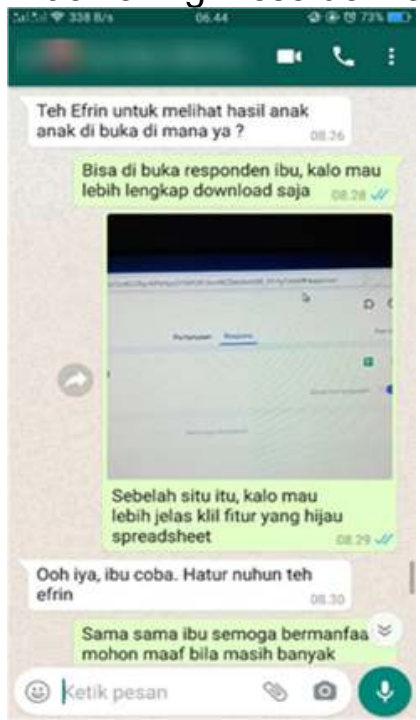

Figure 3. Discussion screenshoot with participants when KulwApp lasted

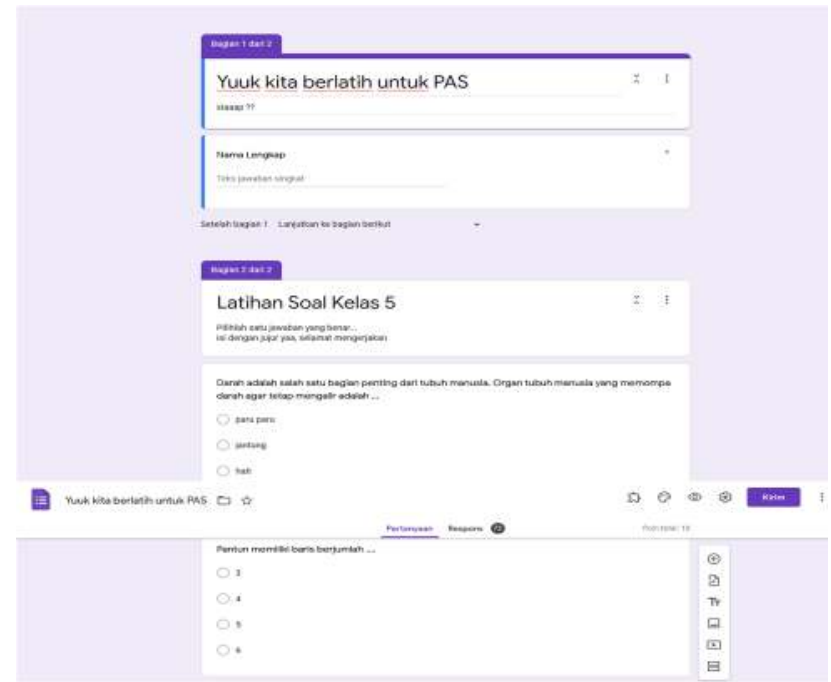

Figure 4. One of the questions on the google form that successfully made by teachers Table 1. Comparison of condition before training and after training

\begin{tabular}{|c|c|c|c|}
\hline No & Before training & During training & After training \\
\hline 1 & $\begin{array}{l}\text { The teacher does not } \\
\text { yet know how to } \\
\text { manufacture online } \\
\text { alternative }\end{array}$ & $\begin{array}{l}\text { training activities give } \\
\text { an introduction, } \\
\text { material about the } \\
\text { features that exist on }\end{array}$ & $\begin{array}{l}\text { Teachers know and can even } \\
\text { make questions with Google } \\
\text { forms independently and are } \\
\text { ready to be applied in online } \\
\text { classes. After the questions are } \\
\text { created, the link will be shared } \\
\text { with students via the WhatsApp } \\
\text { group class. }\end{array}$ \\
\hline 2 & $\begin{array}{l}\text { Teachers have difficulty } \\
\text { in collecting and even } \\
\text { recapitulating the } \\
\text { incoming grades } \\
\text { because they have to } \\
\text { be checked manually in } \\
\text { the WhatsApp group. }\end{array}$ & $\begin{array}{l}\text { the Google Form, and } \\
\text { processing data results } \\
\text { from student answers. }\end{array}$ & $\begin{array}{l}\text { Now it is easier for teachers to } \\
\text { recap the grades entered } \\
\text { because Google Forms provides } \\
\text { integration features with Google } \\
\text { Spreadsheets so that the } \\
\text { student's name is automatically } \\
\text { recorded, the number of times }\end{array}$ \\
\hline
\end{tabular}


On the other hand, in the case, the answer photographed by students can not read properly, because of the lighting(lighting)when capturing the image, blur, angle incorrect, illegible handwriting, and so forth.

Initially, some students were late in collecting results, and of course, it has the potential to interfere with the time. break teacher's

Initially, students were given assignments only in the form of photos in the WhatsApp group

4 class. Thus, the evaluation process tends to be ineffective because it cannot be managed properly

Complaints of parents having difficulty reading questions through photos in assisting students in working on questions. Due to the factor of taking photos that are not right.
Participants are given information regarding the advantages of the Google form that can be applied in schools with the condition of students and parents at SDN Nusa Indah the questions have been filled in, the timestamp (or the time of input data, whether on time or not), the grades obtained.

Teachers can make the average value with further data processing. Unreadable student answers can be minimized because the answers entered on the Google form can be in the form of alphabetic text.

Students are indirectly taught to discipline because the teacher can close access to filling out online evaluation questions on the Google form according to the maximum agreed time.

Later, students will have enthusiasm in doing questions using Google forms, because allow they to charge more than once. Students will have the willingness to study independently more actively to get optimal scores with the available opportunities.

Students can find out their values directly, there is no need to wait for the results of the teacher's recap as well as the implementation in WhatsApp groups.

Parents support innovations in the learning process because Google forms make it easier for parents to guide/accompany their children in doing questions. Unlike questions in the form of photos that must be downloaded first, access to Google form questions is enough by opening the link, then choose the answer from the available questions, finally clicking "send", then the score is out or can be seen directly by students.

\section{Evaluation Stage}

The evaluation results were collected from interviews, criticisms, and suggestions through personal chat and showed that participants were satisfied with the training even though they used KulWapp or instructional textual. The successful implementation of this training activity 
is also in line with the implementation of similar training, as carried out by Yuwono (2020) with the program to increase teacher professional competence through Google forms. Teachers can use ICT optimally during the Covid-19 pandemic so that their duties as educators can be fulfilled. Google forms can be used as an alternative in evaluating learning (Mardiana \& Purwanto, 2017), and if teachers understand the use of Google forms correctly, online learning will be interesting, challenging, and not boring (Batubara, 2016).

The implementation of this training did not escape the supporting factors and obstacles during the training. This activity was successful because it was supported by the participants' enthusiasm who had the will to start learning to create and use Google forms in evaluating learning in their respective classes. The teacher prepares a draft of questions in Ms. Word to support the success of the program. Meanwhile, the obstacle of this activity is the availability of time, where the implementation time is considered short for participants (approximately three hours). Therefore, participants have to rush to understand how to create and use Google forms. Fortunately, communication devices (smartphones and applications WhatsApp) and internet access supporting participants during the training can help reduce confusion from participants. Of course, the implementation will run optimally through training offline or inperson, and the time in practice for making Google forms is longer. Nevertheless, the results of the activities are by the objectives.

\section{CONCLUSIONS AND RECOMMENDATIONS}

Learning evaluation is very important to measure the extent of students' abilities in the learning process. In online learning, Google forms can overcome the obstacles in partner schools (SDN Nusa Indah). Through Google forms, the problem of blurring the results of student assignments (in the form of photos) that makes it difficult for teachers can be overcome; teachers will find it easy to check student exam results and increase student interest in learning. The results of the training show that teachers can practice making questions with Google forms independently. Although parents can help answer questions from the teacher, and it is not easy to verify its validity in practice, at least Google forms are one of the tools that can support online learning.

\section{ACKNOWLEDGMENTS}

This activity is supported by LPPM Universitas Pendidikan Indonesia (UPI) through the Thematic Community Service Program for the Prevention and Mitigation of the Impact of Covid-19 Phase II 2020 in the Education sector. This activity was carried out independently by the author from planning to evaluation. The contents of this article in an audio-visual way are presented at the link following: https://www.youtube.com/watch?v=nO69h1z3wMA (UPI Purwakarta Thematic Community Service Seminar 2020).

\section{REFERENCES}

Aji, R. H. S. (2020). Dampak Covid-19 Pada Pendidikan di Indonesia: Sekolah, Keterampilan, dan Proses Pembelajaran. Salam: Jurnal Sosial Dan Budaya Syar-I, 7(5), 395-402.

Azis, T. N., \& Shalihah, N. M. (2020). Pengembangan Evaluasi Pembelajaran Berbasis Google Form. Tawazun: Jurnal Pendidikan Islam, 13(1), 54-65. https://Doi.Org/10.32832/Tawazun.V13i1.3028

Batubara, H. H. (2016). Workshop Penggunaan Google Form Sebagai Media Evaluasi Pembelajaran Pada Dosen-Dosen Fakultas Studi Islam. Jurnal Pengabdian Al-Ikhlas Universitas Islam Kalimantan Muhammad Arsyad Al Banjary, 2(1), 39-44. http://dx.doi.org/10.31602/jpai.v2i1.961

Buku Pedoman Kuliah Kerja Nyata Tematik Pencegahan dan Penanggulangan Dampak Covid19 Universitas Pendidikan Indonesia. (n.d.). Retrieved 8 January 2021, from http://lppm.upi.edu/berita/detail/buku-pedoman-kuliah-kerja-nyata-tematik-pencegahandan-penanggulangan-dampak-covid19 
Chandrawati, S. R. (2010). Pemanfaatan E-Learning Dalam Pembelajaran. Jurnal Cakrawala Kependidikan, 8(2), 218616.

Cristina, R. (2017). Use Google Forms for Evaluation: Google Forms and Quizzes As Effective Teaching Tools (Kindle). https://www.amazon.com/Use-Google-forms-evaluationeducational/dp/1796493961

Dewi, W. A. F. (2020). Dampak Covid-19 Terhadap Implementasi Pembelajaran Daring Di Sekolah Dasar. Edukatif: Jurnal IImu Pendidikan, 2(1), 55-61. https://Doi.Org/10.31004/Edukatif.V2i1.89

Fahrudin, A.R., (2020). Permasalahan dan Solusi Pembelajaran Jarak Jauh Di Masa Pandemi

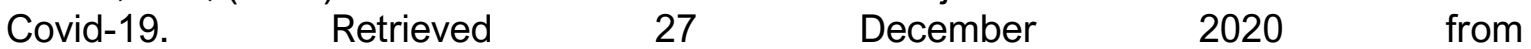
https://sapos.co.id/2020/11/29/permasalahan-dan-solusi-pembelajaran-jarak-jauh-dimasa-pandemi-covid-19/

Jamun, Y. M. (2018). Dampak Teknologi Terhadap Pendidikan. Jurnal Pendidikan dan Kebudayaan Missio, 10(1), 48-52.

Kurniawati, R., \& Fuada, S. (2021). Pemanfaatan Linktree, Google Form, Youtube dan Quizizz sebagai Media Bantu Pembelajaran Daring Selama Periode Adaptasi Baru di SDN Dayeuhkolot II Subang. Indonesian Journal of Community Services in Engineering \& Education (IJOCSEE), 1(2).

Majid, N. A., \& Fuada, S. (2020). E-Learning for Society: A Great Potential to Implement Education for All (EFA) Movement in Indonesia. Int. J. of Interactive Mobile Technologies, 14 (2), 250-258.

Majid, N. W. A., Fuada, S., Fajri, M. K., Nurtanto, M., \& Akbar, R. (2020). Progress report of cyber society v1. 0 development as a learning media for Indonesian society to support EFA. Int. J. Eng. Pedagogy, 10(4), 133-145.

Mardiana, T., \& Purnanto, A. W. (2017). Google Form sebagai Alternatif Pembuatan Latihan Soal Evaluasi, Urecol, 6(1), 183-188

Purwati, D., \& Nugroho, A. N. P. (2018). Pengembangan Media Evaluasi Pembelajaran Sejarah Berbasis Google Formulir di SMAN 1 Prambanan. Istoria: Jurnal Pendidikan Dan IImu Sejarah, 14(1). https://Doi.Org/10.21831/Istoria.V14i1.19398

Ritonga, M., Lahmi, A., Rimelfi, R., Bahri, F., \& Bagindo, I. T. (2020). Sosialisasi Pembuatan Soal Melalui Google Form Dalam Meningkatkan Kompetensi Guru PAI. Bernas: Jurnal Pengabdian Kepada Masyarakat, 1(4), 347-354. https://doi.org/10.31949/Jb.V1i4.456

Yuwono, M. R., Ariwibowo, E. K., Firmansyah, F., \& Indrayanto, B. (2020). Pelatihan Anbuso, Zipgrade, dan Google Form sebagai Alternatif Penilaian Pembelajaran di Era Digital, MARTABE: Jurnal Pengabdian Masyarakat, 3(1). 49-61. 